\title{
Influence of Supplementary Bioavailable Carbon on the Thermal and Biological Kinetic Parameters of the Composting Process of Tomato Plant Trimmings
}

\author{
A.E. Ghaly and F. Alkoaik \\ Biological Engineering Department, Dalhousie University, P.O. Box 1000 \\ Halifax, Nova Scotia, Canada B3J 2K9
}

\begin{abstract}
Three laboratory-scale bioreactors were used to investigate the influence of bioavailable carbon addition on the composting process of tomato remains. Sugar, cheese whey and used cooking oil were used as bioavailable carbon sources. The amounts of materials added to the compost mixture had equal energy contents. The initial moisture contents and $\mathrm{C}$ : $\mathrm{N}$ ratios of the compost mixtures were maintained at $60 \%$ and 30: 1, respectively. The average bioreactor temperature was strongly influenced by the type of bioavailable carbon. The maximum bioreactor temperature was 50.8, 56.9, 63.4 and $63.3{ }^{\circ} \mathrm{C}$ for the control and the mixtures receiving sugar, cheese whey and used cooking oil, respectively. Strong correlations were observed between the maximum temperature achieved (and its duration) and the reductions in fat and volatile solids contents. The total fat reductions were in the range of 64.6-88.8\%, whereas the total carbohydrates reductions were in the range of $21.5-31.7 \%$. Reductions of 12.4-25.3\% and 3.5-17.7\% were also achieved in protein content and TKN. Neither the nitrogen nor the moisture contents were limiting factors. The ammonium nitrogen remained unchanged at $0.33-0.35 \%$ and the moisture content remained at $59.7 \pm 0.61 \%$.
\end{abstract}

Key words: Compost, bioavailable carbon, tomato remains, volatile solids, carbohydrate, protein, fat

\section{INTRODUCTION}

Green house tomato production represents $58 \%$ of the greenhouse total vegetable production in Canada in 2000 , with a production area of 1550 hectares, yielding 182,736 tonnes $^{[1]}$. There is a considerable amount of plant residues as a result of trimming and after harvesting the crop that must be disposed off properly. A typical greenhouse operation produces 40-60 tonnes of organic residues per hectare per year which are usually piled near greenhouses or burned ${ }^{[2]}$. These practices cause several undesirable agronomic and environmental problems, since these plants were subjected to intensive pesticide application to control insects and diseases. Therefore, management of these crop residues is necessary in order to minimize their adverse effects, especially recycling plant pathogens ${ }^{[3]}$.

According to $\operatorname{NSDAFF}^{[4]}$ and $\mathrm{ODAF}^{[2]}$, composting of greenhouse residues is considered the preferred organic waste management method. However, plant biomass is mainly composed of lignin, cellulose and hemicellulose $\mathrm{e}^{[5]}$. Lignin surrounds the cellulose and hemicellulose fibers protecting them from the microbial $\operatorname{attack}^{[6]}$. Therefore, plant residues are usually lacking bioavailable carbon and are mostly considered as bulking agents when designing a composting mixture ${ }^{[7]}$. While composting tomato plant residues, Alkoaik and Ghaly ${ }^{[8]}$ found that most of the carbon in the composting mixture was not readily available and the temperature never exceeded $50{ }^{\circ} \mathrm{C}$. Therefore, readily available type of carbon source is needed to start the composting process and maintain the duration of thermophilic temperature required to sanitize the composted mixture.

The main objective of this study was to investigate the suitability of different bioavailable carbon sources and their effects on the thermal (lag period, rate of temperature rise, maximum temperature and duration of the maximum temperature) and biological (moisture content, volatile solids, nitrogenous compounds, total carbohydrates, protein and fat and grease) parameters of the composting process of tomato plant residues.

\section{MATERIALS AND METHODS}

The experimental set up shown in Fig. 1 consisted of a frame, three bioreactors, mixing units, air supply units and data acquisition system.

The vertical part of the frame was made of three $3.2 \mathrm{~mm}$ thick aluminum sheets (the central one measured 330x1100 $\mathrm{mm}$ and the two side sheets measured 140x1100 mm each.) soldered together making a vertical channel (U-shaped) with a length of $1100 \mathrm{~mm}$, a width of $330 \mathrm{~mm}$ and a depth of $140 \mathrm{~mm}$. The U-shaped stand held the mixing motors, flow meters, air and exhaust gas manifolds, tubing and the thermocouple wires. The horizontal part of the frame was made of three $50 \times 50 \mathrm{~mm}$ aluminum angles $(3.2$ $\mathrm{mm}$ thick and permanently soldered together), two of which measured $700 \mathrm{~mm}$ and were fixed to the vertical

Corresponding Author: A.E. Ghaly, Biological Engineering Department, Dalhousie University, P.O.Box 1000, Halifax, Nova Scotia, Canada B3J 2K9, Tel: (902) 494-6014, Fax: (902) 423-2423 
part by means of four $6 \mathrm{~mm}$ diameter stainless steel bolts and nuts, whereas the third one measured $328 \mathrm{~mm}$ and kept the other two angles $330 \mathrm{~mm}$ apart.

Each bioreactor was constructed of polyvinyl chloride (PVC) tube having a length of $520 \mathrm{~mm}$, an inside diameter of $20 . \mathrm{mm}$ and a wall thickness of $5 \mathrm{~mm}$ (Fig. 2). A removable circular Plexiglas plate (for cleaning purpose) of $203 \mathrm{~mm}$ diameter and $6 \mathrm{~mm}$ thickness was recessed and secured into the cylinder by means of six stainless steel screws $(6 \mathrm{~mm})$. A rubber gasket lining (O-ring, $2.5 \mathrm{~mm}$ thick) was added to the inner side of the removable circular plate to keep it tight. There was a small circular window $(64 \mathrm{~mm}$ in diameter) on the removable circular plate, which was closed with a rubber stopper (No.13) and used as a sampling port. The other side of the tube was covered with a fixed circular PVC plate of $203 \mathrm{~mm}$ diameter and $6 \mathrm{~mm}$ thickness which was glued into the tube and secured by means of six stainless steel screws $(6 \mathrm{~mm})$. Each reactor was fitted into an aluminum ring, which was fastened into the frame by means of four bolts ( 6 $\mathrm{mm}$ ) and nuts. Both the removable and fixed circular plates were insulated with $38.1 \mathrm{~mm}$ thick Styrofoam layer, while the tube was insulated with 38.1-mm thick Fibreglass. The three bioreactors were fixed into the frame.

There were three holes at the bottom and one at the top of the bioreactor, which were drilled and threaded to take a $12 \mathrm{~mm}$ nylon hose barb. The three holes at the bottom were connected to a manifold by $6.4 \mathrm{~mm}$ diameter tygon tubing and used for aeration, whereas the fourth one at the top was used for the exhaust gas. The air was supplied continuously to the bottom of the bioreactor from the laboratory air supply. It passed through a pressure regulator and a pressure gage to maintain the pressure around $5 \mathrm{kPa}$. The regulated air then passed through a water bath to humidify the inlet air to nearly $100 \%$ saturation and then passed through a flow meter (Model 32461-14, Cole-Parmer Instrument Company, Vernon Hills. Illinois. USA). The flow meter can measure a flow in the range of $0.0566-0.566 \mathrm{~m}^{3} \mathrm{~h}^{-1}$.

Inside each bioreactor, a removable $10.5 \mathrm{~mm}$ diameter solid stainless steel shaft was mounted on two bearings. There were 5 stainless steel collars on the shaft in which five bolts of $69 \mathrm{~mm}$ in length and $6 \mathrm{~mm}$ diameter each were mounted. The shaft was rotated $(5.76 \mathrm{rpm})$ by a thermally protected electric motor (Model No. 127P1486/B, D. C., Sigma Instruments Inc., Braintree, Mass, USA).

The data acquisition unit consisted of a master unit, a thermocouple scanning card, a software, temperature sensors, a personal computer and a printer. The master unit (Multiscan 1200, Omega, Stamford, CT) was connected to a computer via RS 232 interface. The Thermocouple/Volt Scanning Card (MTC/24, Omega, Stamford, CT) contained 24 isolated differential input channels. A window-based (Tempview) software, that featured a graphical spreadsheet-style user interface, allowed easy configurations of hardware and the acquisition and displays parameters. Four type T (copper-constantan) thermocouples (Cole Parmer, Chicago, IL, USA) were used for each bioreactor for temperature measurements. Three thermocouples were located at the bottom of the bioreactor and were used to measure the temperature of the compost mass whereas the fourth was located at the top of the bioreactor, near the outlet air exit $(21 \mathrm{~mm}$ away) and was used to measure the temperature of the exhaust gas. Thermocouple locations, on the bottom of all bioreactors, were chosen to be far enough from the inlet air (65 mm away). An IBM personal computer (Pentium IV) was used. The computer had a R232 C serial synchronous communications interface and centronics parallel printer interface. An hp (Hewlett Packard) laser jet4 printer was used.

Tomato plant residues: The tomato plant residues (leaves, stems and some fruits) were collected in polyethylene bags (13 kg each) from a large commercial greenhouse in Truro, Nova Scotia at an average moisture content (MC) of approximately $90 \%$. The bags were transported to the Waste Management Laboratory and the tomato plant residues were left over night at room temperature $\left(\approx 25{ }^{\circ} \mathrm{C}\right)$ to partially dry (MC $76 \%$ ) and then chopped into small pieces using a shredder (Model 242A645-515, SHP, Briggs and Stratton, Plainfield, NJ, USA). Some characteristics of the chopped tomato plant mixture (stems, leaves and fruits) are presented in Table 1.

Wood shavings: The wood shavings were collected in small polyethylene bags $(\sim 5 \mathrm{~kg})$ from a commercial wood lumber mill in Sackville, Nova Scotia and transported to the Waste Management Laboratory. Some characteristics of the wood shavings are presented in Table 1.

Inoculum: A 15-day old municipal solid waste compost was obtained from a municipal solid waste composting (MSWC) facility operated by Miller Composting Corporation in Dartmouth, Nova Scotia. It was added to the mixture in order to introduce a wide range of active composting microorganisms. Some characteristics of the municipal solid waste compost are presented in Table 1.

Urea (nitrogen source): Urea [CO $\left.\left(\mathrm{NH}_{2}\right)_{2}\right]$ was used in this study as a nitrogen source to adjust the $\mathrm{C}: \mathrm{N}$ ratio to $30: 1$. The choice of Urea ( $46 \%$ nitrogen) was based on the recommendation of Manios and Balis ${ }^{[9]}$, an effective source of nitrogen for omposting than $\left(\mathrm{NH}_{4}\right)_{2} \mathrm{SO}_{4}$ and $\mathrm{KNO}_{3}$ in initiating and maintaining intense respiratory activity. It was purchased from Halifax Seed Co. Inc. in Halifax, Nova Scotia. The quantity of nitrogen required was calculated as follows ${ }^{[10]}$ : 


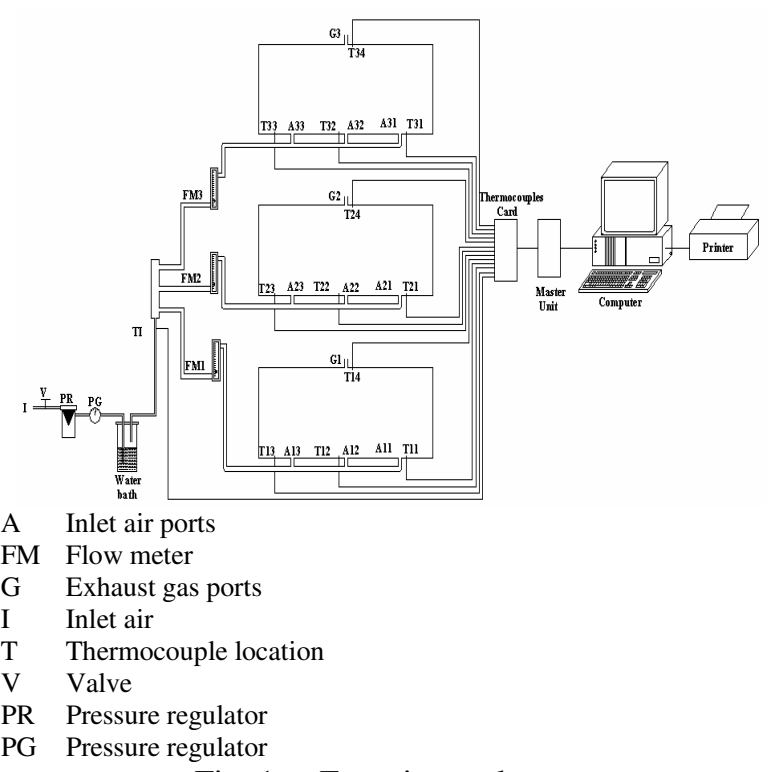

Fig. 1: Experimental setup

Table 1: Some characteristics of tomato residues, wood shaving and municipal solid waste compost

\begin{tabular}{|c|c|c|c|}
\hline Characteristics & $\begin{array}{l}\text { Tomato Plant } \\
\text { Remains }\end{array}$ & $\begin{array}{l}\text { Wood } \\
\text { shavings }\end{array}$ & $\begin{array}{l}\text { Municipal solid } \\
\text { waste compost }\end{array}$ \\
\hline Moisture Content (\%) & 76.0 & 8.0 & 58.6 \\
\hline \multicolumn{4}{|l|}{$\begin{array}{l}\text { Total solids (TS) } \\
\text { (mg/g DM) }\end{array}$} \\
\hline 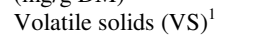 & 693.0 & 997.4 & 854.6 \\
\hline Ash & 307.0 & 2.6 & 145.4 \\
\hline \multicolumn{4}{|l|}{ Nitrogen (mg/g DM) } \\
\hline Total Kjeldahl Nitrogen & 27.0 & 1.0 & 18.0 \\
\hline Ammonium Nitrogen & 2.2 & 0.2 & 5.2 \\
\hline \multicolumn{4}{|l|}{ Carbon (mg/g DM) } \\
\hline Total & 327.0 & 499.0 & 440.0 \\
\hline Organic & 260.0 & 390.0 & 350.0 \\
\hline \multicolumn{4}{|l|}{$\begin{array}{l}\text { Elemental Composition } \\
(\mathrm{mg} / \mathrm{g} \text { DM) }\end{array}$} \\
\hline $\mathrm{Ca}$ & 51.0 & 0.8 & 20.0 \\
\hline $\mathrm{Na}$ & 0.7 & 0.0 & 6.2 \\
\hline $\mathrm{Fe}$ & 0.4 & 0.0 & 2.8 \\
\hline $\mathrm{Mg}$ & 4.7 & 0.1 & 1.8 \\
\hline $\mathrm{Zn}$ & 0.0 & 0.0 & 0.1 \\
\hline $\mathrm{K}$ & 57.6 & 0.6 & 7.8 \\
\hline $\mathrm{Cl}$ & 0.07 & 0.0 & 0.3 \\
\hline $\mathrm{P}$ & 10.5 & 0.0 & 2.7 \\
\hline $\mathrm{s}$ & 7.9 & 0.9 & 2.3 \\
\hline Others ${ }^{1}$ & 174.1 & 0.2 & 101.4 \\
\hline
\end{tabular}

Nitrogen required $=($ total carbon $/$ desired $\mathrm{C}: \mathrm{N})$

- total available nitrogen

Sugar: Commercial sugar was purchased from the Atlantic Super Store in Halifax, Nova Scotia. Sugar solution was prepared by dissolving 666.7 grams of sugar in $1 \mathrm{~L}$ distilled deionized water.

Cheese whey: The cheese whey was obtained from Farmer's Cooperative Dairy Plant in Truro, Nova Scotia, in 60-L plastic containers. The container were sealed and transported to the Waste Management Laboratory and stored in a freezer at $-10{ }^{\circ} \mathrm{C}$ until required. Some characteristics of the cheese whey are presented in Table 2.
Table 2: Some characteristics of cheese whey and used cooking oil

\begin{tabular}{lcr}
\hline Characteristics & Cheese Whey & \multicolumn{1}{c}{ Used Oil } \\
\hline Moisture Content (\%) & 93.2 & -- \\
Total solids (TS) $(\mathrm{mg} / \mathrm{L})$ & & \\
Volatile solids (VS) & & \\
Ash & 61550.0 & 999500.00 \\
Nitrogen (mg/L) & 6750.0 & 500.00 \\
Total Kjeldahl Nitrogen & & \\
Ammonium Nitrogen & 1560.0 & 200.00 \\
Elemental Composition (mg/L) & 260.0 & 0.40 \\
$\mathrm{Ca}$ & & \\
$\mathrm{Na}$ & 429.0 & 52.00 \\
$\mathrm{Fe}$ & 684.0 & 273.00 \\
$\mathrm{Mg}$ & 42.0 & 13.00 \\
$\mathrm{~K}$ & 94.0 & 7.00 \\
$\mathrm{Cl}$ & 1670.0 & 9.00 \\
$\mathrm{P}$ & -- & 674.00 \\
$\mathrm{~S}$ & 154.0 & $<9.80$ \\
Others ${ }^{2}$ & 483.0 & 2110.00 \\
Total Oil and Grease (mg/L) & 3677.0 & 146.00 \\
Carbohydrates (mg/L) & 4700.0 & $908,000.00$ \\
Proteins (mg/L) & $50,000.0$ & 80255.00 \\
pH & 8125.0 & 1247.50 \\
${ }^{1}$ Volatile solids are the organic matter (largely carbon, oxygen and \\
nitrogen) which are lost at 550 ${ }^{\circ} \mathrm{C}$, leaving only the ash. \\
${ }^{2}$ Others include mostly silica and other elements.
\end{tabular}

Used cooking oil: The used cooking oil was obtained from a local fast food restaurant in Halifax, Nova Scotia. It was stored at room temperature in the Waste Management Laboratory until required. Some characteristics of the used cooking oil are presented in Table 2.

System preparation: The temperature sensors were calibrated using ice and boiling water bathes. The thermocouples including the fittings were immersed into the ice bath and hooked up to the data acquisition system individually. The thermocouple readings were corrected to read zero ${ }^{\circ} \mathrm{C}$ (offset). They were then immersed into the boiling water bath to correct the upper limit. Before each run, temperature sensors were tested for $24 \mathrm{~h}$ in an empty bioreactor and the temperature readings were always within $\pm 0.5^{\circ} \mathrm{C}$ of the reactor temperature (measured with thermometer), which is within the accuracy range of the thermocouple (Type T).

Mixtures preparation: The chopped tomato plant residues were mixed with wood shavings (1: 1.5 dry basis) and then ground in a hammer mill (Model C-H, Horvick Manufacturing, INC. Moorhead. Minnesota, USA). Particle size analysis was performed on the final mixture according to the procedure described by Kunii and Levenspiel ${ }^{[11]}$ and the average particle size was found to be $6.0 \mathrm{~mm}$. The ground tomato plant residueswood shavings mixture was tightly bagged and placed in a freezer until needed.

A mixture of tomato plant residues: wood shavings: municipal solid waste compost at a ratio of 2.5:0.28 (1: 1.5: 0.28 , tomato plant residues: wood shavings: municipal solid waste compost) was prepared for the composting experiments. 


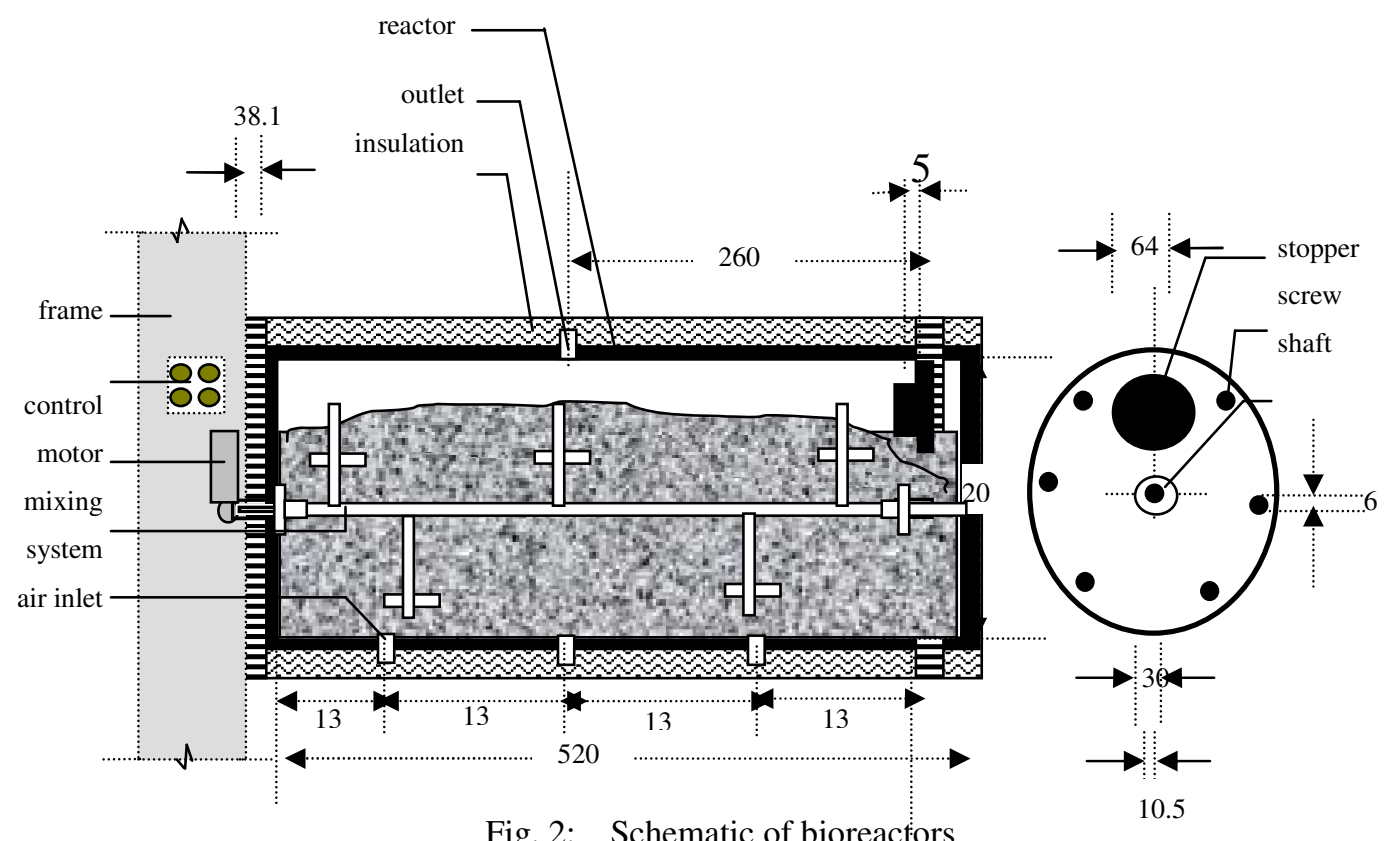

Fig. 2: Schematic of bioreactors

Table 3: The constituents of the mixture used in the study

\begin{tabular}{|c|c|c|c|c|}
\hline Parameter & Control mixture $^{\mathrm{A}}$ & Mixture with sugar & Mixture with cheese whey & Mixture with used oil \\
\hline Tomato plant residues ${ }^{\mathrm{B}}(\%)$ & 36.0 & 36.0 & 36.0 & 36.0 \\
\hline Wood shavings (\%) & 54.0 & 54.0 & 54.0 & 54.0 \\
\hline Municipal Compost (\%) & 10.0 & 10.0 & 10.0 & 10.0 \\
\hline Moisture content (\%) & 60.0 & 60.0 & 60.0 & 60.0 \\
\hline Total dry weight ${ }^{\mathrm{C}}(\mathrm{g})$ & 1400.0 & 1400.0 & 1400.0 & 1400.0 \\
\hline Initial $\mathrm{C}: \mathrm{N}$ ratio & $35.8: 1$ & $35.8: 1^{\mathrm{D}}$ & $30.5: 1$ & $38.3: 1$ \\
\hline Urea required $(\mathrm{g})$ & 7.2 & 7.2 & 0.8 & 10.3 \\
\hline Final C: $\mathrm{N}$ ratio & $30: 1$ & $30: 1$ & 30:1 & $30: 1$ \\
\hline
\end{tabular}

A No whey or oil added.

B Tomato plant residues $=$ tomato leaves, stems and fruits.

C Total mixture wet weight $=3.5 \mathrm{~kg}$.

D The initial mixture is the same as that used in the control since sugar was added later.

The $\mathrm{C}$ : $\mathrm{N}$ ratio was determined for the mixture and corrected to $30: 1$ by the addition of Urea (46\% nitrogen). The moisture content of each mixture was also adjusted to approximately $60 \%$.

Experimental design: Two sets of experiments were performed in this study. The first set of experiments were conducted using sugar solution $\left(6678 \mathrm{~g} \mathrm{~L}^{-1}\right)$ to determine whether the bioavailable carbon in the final tomato plant residues-wood shaving-MSWC mixture is limited as suggested by Alkoaik and Ghaly ${ }^{[8]}$. The second set of experiments were dedicated to investigating the addition of other wastes, as bioavailable carbon sources on the performance of the composting process.

In the first set of experiments, the moisture content was adjusted to $60 \%$ using water. A volume of $150 \mathrm{ml}$ of sugar solution was added to each of the first, second and third bioreactors before the temperatures started to decline (after $24 \mathrm{~h}$ ). Another $150 \mathrm{ml}$ of the sugar solution was added to each of the second and third bioreactors before the temperature started to decline (after $36 \mathrm{~h}$ ). Finally, a third sugar application of $150 \mathrm{ml}$ was added to the third bioreactor before the temperature started to decline (after $48 \mathrm{~h}$ ). The fourth reactor was used as a control (no sugar was added).

In the second set of experiments, cheese whey and used cooking oil were used as bioavailable carbon sources based on their availability in the local area. Preliminary analyses were first performed on these sources to determine their energy contents. The fat content was 908 and $5 \mathrm{~g}$ fat $\mathrm{L}^{-1}$ for used cooking oil and cheese whey, respectively. Cheese whey had also $50 \mathrm{~g}$ Lactose $\mathrm{L}^{-1}$. A volume of $1.92 \mathrm{~L}$ of cheese whey was added to $1.8 \mathrm{~kg}$ of the mixture of tomato plant residues: wood shavings: MSWC to bring the moisture content to $60 \%$. This mixture had additional energy content (from the cheese whey) of $2243.5 \mathrm{~kJ}$, which was determined from the following equation:

Energy Content $(\mathrm{kJ} / 100 \mathrm{~g})=$ [Carbohydrates $\times 16.8$ ]

$$
+[\text { Proteins } \times 16.8]+[\text { Fats } \times 35]
$$

Both whey and oil containing mixtures had identical energy contents. Since used cooking oil had energy content of $35 \mathrm{~kJ} \mathrm{~mL}^{-1}$, about $64.1 \mathrm{~mL}$ of used 
cooking oil was, therefore, added to $1.8 \mathrm{~kg}$ mixture of tomato plant residues: wood shavings: MSWC. Water was used to bring the moisture content to $60 \%$. A mixture without whey or oil addition was used as a control.

Experimental protocol: The $\mathrm{C}$ : $\mathrm{N}$ ratio was adjusted to $30: 1$ by the addition of Urea ( $46 \%$ nitrogen). The compositions of the final mixtures used in the study are shown in Table 3. The final mixture used in each experiment was mixed well and then placed in the bioreactor which occupied $75 \%$ of the total volume of the bioreactor (or $0.012 \mathrm{~m}^{3}$ ). The side Plexiglas wall was put in place. The mixing unit was run continuously at 5 RPM and the air flow rate was maintained at 0.15 $\mathrm{m}^{3} \mathrm{~h}^{-1}\left(2.5 \mathrm{~L} \mathrm{~min}^{-1}\right.$ or 0.17 volume per volume per minute) during all experiments.

Measurements and analyses: Temperature was continuously monitored during the study. Samples of approximately 150 grams were taken at the start and end of each run for moisture content, solids (total,volatile and fixed) and nitrogen (total kjeldahl nitrogen and ammonium nitrogen) analyses. The moisture content was performed using oven-drying method, following ASTM (D3173-73) procedure ${ }^{[13]}$. The proximate analysis was performed to determine the weight faction of volatiles and ash in the compost mixture according to the Standard Method for Proximate Analysis of Coal and Coke ${ }^{[12]}$. Both the total kjeldahl nitrogen (TKN) and ammonium nitrogen $\left(\mathrm{NH}_{4}-\mathrm{N}\right)$ were determined using a KjelTech Auto Analyzer (Tecator, Model 1030. Herndon, VA. USA). The organic nitrogen (ON) was calculated by subfraction $\left(\mathrm{TKN}-\mathrm{NH}_{4}-\mathrm{N}\right)$. Crude protein was calculated as the follows:

Crude Protein $=$ ON X 6.25

Total fat and grease was analyzed following EPA method 1664 procedure $^{[13]}$. Total carbohydrates were calculated according to the following mass balance equation:

Total Carbohydrate $=100 \%$ -

(Proteins $\%+$ Fat $\%+$ Mc \% + Ash \%)

The composted materials $\mathrm{pH}$ was measured using Fisher Accumet pH meter (Model 805 MP. Fisher Scientific. Pittsburgh, PA, USA). A 50 to $100 \mathrm{~cm}^{3}$ sample of the composted material was diluted 1:10 (v:v) with distilled-deionized water and placed in a mechanical shaker at $230 \mathrm{rpm}$ for 30 minutes prior to $\mathrm{pH}$ measurement.

\section{RESULTS AND DISCUSSION}

Addition of sugar: The profiles of the average bioreactors temperatures $\left(\mathrm{T}_{\text {ave }}\right)$ and the inlet air temperature (Ti) are presented in Fig. 3. The maximum temperatures, time of peak and duration are presented in Table 4. Maximum temperatures of 50.8, 56.9, 61.8
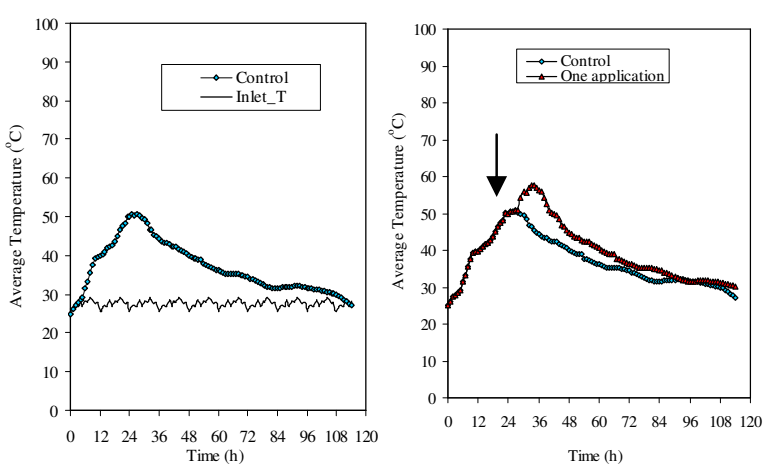

a. Control

b. One application

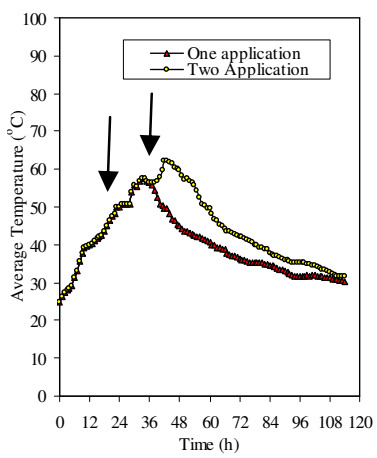

c. Two applications

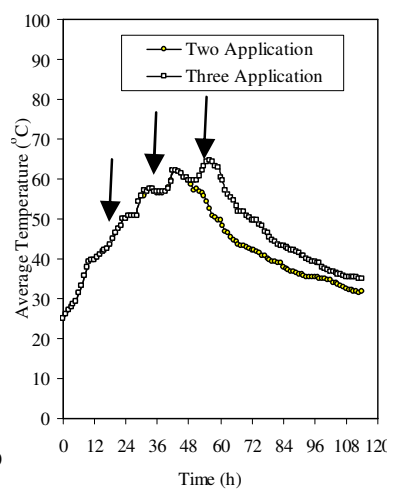

d. Three applications

Fig. 3: The temperature profiles of the sugar experiments

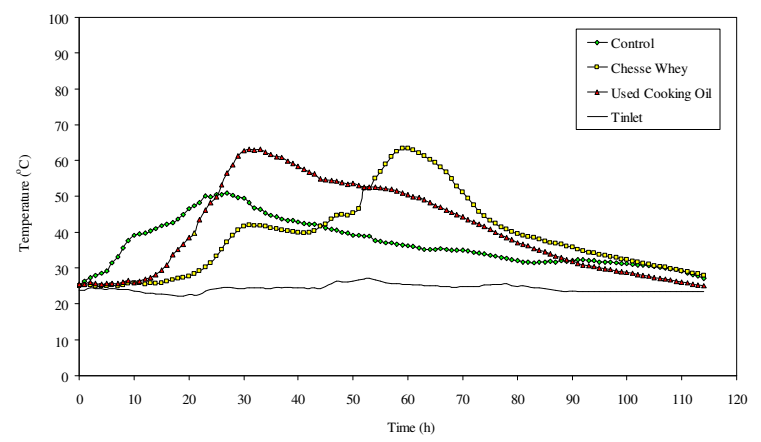

Fig. 4: Temperature profiles of the cheese whey and cooking oil experiments

and $64.3^{\circ} \mathrm{C}$ were reached after $27,35,44$ and 57 hours in the control bioreactor and the bioreactors with one, two and three sugar applications, respectively. Temperatures higher than or equal to $50^{\circ} \mathrm{C}$ were maintained in the control bioreactor and the reactors with one, two and three sugar applications and lasted for 5, 20, 36 and 50 hours, respectively. Temperatures higher than $55^{\circ} \mathrm{C}$ were observed in bioreactors with one, two and three sugar applications and lasted for 7 , 24 and 35 hours, respectively. Only the bioreactors with two and three sugar applications had a temperature of 60 or higher which lasted 7 and 20 hours, respectively.

Microorganisms break down simple organic molecules (sugar) immediately and use them for growth 
Am. J. Environ. Sci., 2 (1): 15-26, 2006

Table 4: Temperature ranges and duration observed during the sugar experiment

\begin{tabular}{|c|c|c|c|c|c|c|c|c|}
\hline \multirow[b]{2}{*}{ Treatment } & \multirow{2}{*}{$\begin{array}{l}\text { Maximum } \\
\text { Temperature }\left({ }^{\circ} \mathrm{C}\right)\end{array}$} & \multirow{2}{*}{$\begin{array}{l}\text { Time of Peak } \\
\text { (h) }\end{array}$} & \multicolumn{6}{|c|}{ Duration of the Temperature $\geq(\mathrm{h})$} \\
\hline & & & $35^{\circ} \mathrm{C}$ & $40^{\circ} \mathrm{C}$ & $45^{\circ} \mathrm{C}$ & $50^{\circ} \mathrm{C}$ & $55^{\circ} \mathrm{C}$ & $60^{\circ} \mathrm{C}$ \\
\hline Without Sugar & 50.8 & 27 & 63 & 37 & 16 & 5 & 0 & 0 \\
\hline With Sugar & & & & & & & & \\
\hline One Application & 56.9 & 35 & 78 & 51 & 32 & 20 & 7 & 0 \\
\hline Two Applications & 61.8 & 44 & 94 & 68 & 46 & 36 & 24 & 7 \\
\hline Three Applications & 64.3 & 57 & 106 & 81 & 61 & 50 & 35 & 20 \\
\hline
\end{tabular}

Table 5: Temperatures and durations observed during the cheese whey and used cooking oil experiments

\begin{tabular}{|c|c|c|c|c|c|c|c|c|}
\hline \multirow[b]{2}{*}{ Treatment } & \multirow[b]{2}{*}{$\begin{array}{l}\text { Maximum } \\
\text { Temperature }\left({ }^{\circ} \mathrm{C}\right)\end{array}$} & \multirow[b]{2}{*}{$\begin{array}{l}\text { Time of Peak } \\
\text { (h) }\end{array}$} & \multicolumn{6}{|c|}{ Duration of the Temperature $\geq(\mathrm{h})$} \\
\hline & & & $35^{\circ} \mathrm{C}$ & $40^{\circ} \mathrm{C}$ & $45^{\circ} \mathrm{C}$ & $50^{\circ} \mathrm{C}$ & $55^{\circ} \mathrm{C}$ & $60^{\circ} \mathrm{C}$ \\
\hline Control & 50.8 & 27 & 54 & 37 & 16 & 5 & 0 & 0 \\
\hline Cheese Whey & 63.4 & 60.0 & 66 & 50 & 26 & 19 & 14 & 9 \\
\hline Used Oil & 63.3 & 31.0 & 66 & 55 & 46 & 36 & 17 & 9 \\
\hline
\end{tabular}

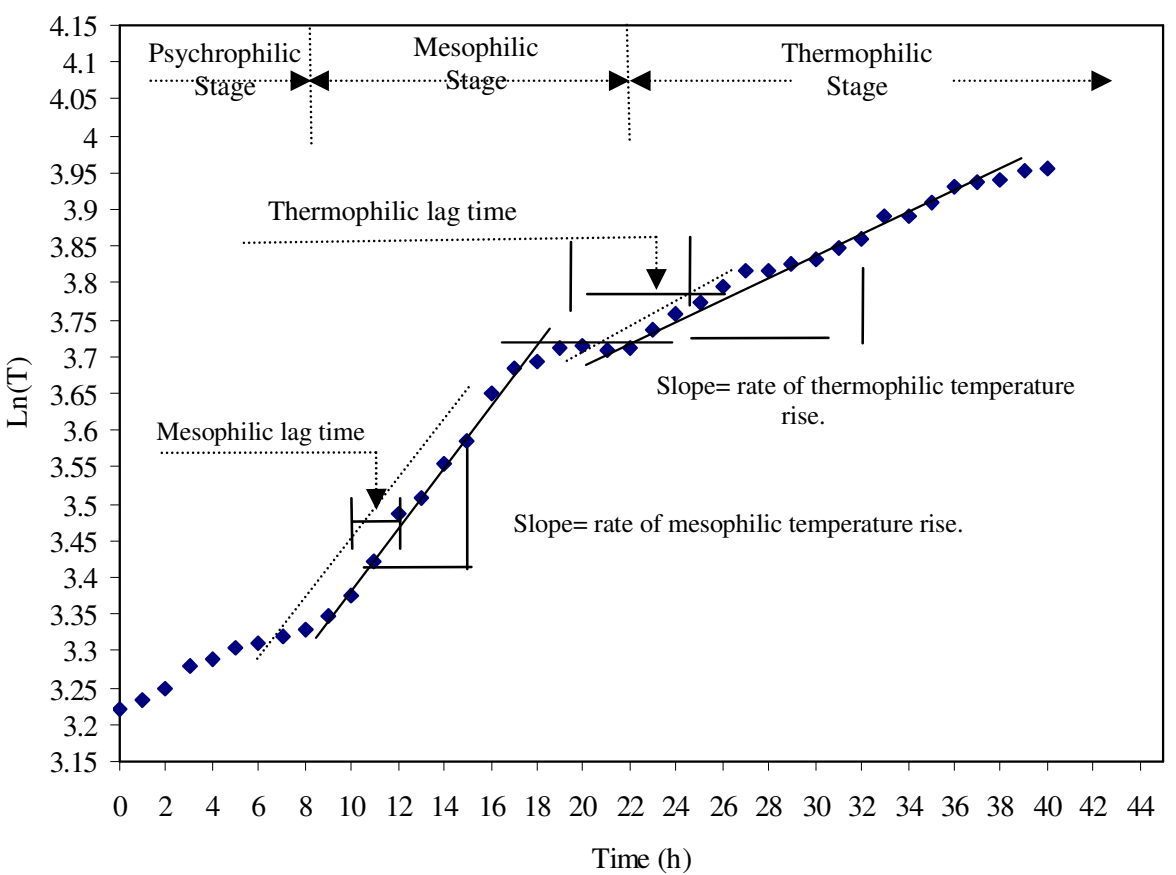

Fig. 5: Determination of the mesophilic and thermophilic lag periods and rates of temperature increase

and reproduction ${ }^{[14,15]}$. As carbon compounds decompose under aerobic condition, part of the organic carbon is converted to microbial cell mass, while the other part is converted to energy with the release of $\mathrm{CO}_{2}$ and water as shown by the following equations ${ }^{[14]}$ :

Energy: $\mathrm{C}_{\mathrm{x}} \mathrm{H}_{\mathrm{y}} \mathrm{O}_{\mathrm{z}}+6 \mathrm{O}_{2}$

$\mathrm{CO}_{2}+\mathrm{H}_{2} \mathrm{O}+\mathrm{HEAT}$

Growth: $\mathrm{C}_{\mathrm{x}} \mathrm{H}_{\mathrm{y}} \mathrm{O}_{\mathrm{z}}+\mathrm{NH}_{4}$

$\mathrm{C}_{7} \mathrm{H}_{5} \mathrm{O}_{2} \mathrm{~N}$ (more microbes)

The average bioreactors temperatures $\left(\mathrm{T}_{\mathrm{ave}}\right)$ gradually increased as a result of heat being produced (3.76 kcal g ${ }^{-1}$ decomposed) due to microbial metabolism ${ }^{[16]}$.

It is clear from the results that the effect of the sugar as a source of readily available carbon on the average temperature in the bioreactor was positive. The maximum temperature in the control bioreactor (without sugar) was only $50.8^{\circ} \mathrm{C}$ and remained for very shot time $(5 \mathrm{~h})$ before starting to decline. The average temperature in the other bioreactors which had the similar mixtures but with sugar applications, continued to rise and temperatures higher than $50{ }^{\circ} \mathrm{C}$ were maintained for longer periods. The results indicated that the bioavailable carbon in the compost material was somewhat limited and the addition of readily bioavailable carbon source (sugar) increased the microbial activity and resulted in higher temperature. Rahn and Lillywhite ${ }^{[17]}$ studied the influence of the carbon source of 13 vegetable crop residues on the degradation rate and concluded that the decomposition rate correlated to the amount of bioavailable carbon and nitrogen contents of the material and that the organic matter remaining after the process correlated with the nonbioavailable carbon (lignin content) of the source material. The addition of sugar to the tomato plant 
residue-wood shaving-MSWC mixture raised the bioreactor temperature to the thermophilic stage but the duration of that stage depended on the amount of sugar added.

\section{Addition of cheese whey and used cooking oil}

Temperature: The profiles of the average temperatures $\left(\mathrm{T}_{\text {ave }}\right)$ of the bioreactors are presented in Fig. 4. The maximum temperatures and their peak times are presented in Table 5. The average maximum temperature in the control bioreactor and the bioreactors containing cheese whey and used cooking oil reached 50.8, 63.4 and $63.3{ }^{\circ} \mathrm{C}$ after 27,60 and 31 hours, respectively. Temperatures higher than $55{ }^{\circ} \mathrm{C}$ were observed only in the bioreactors containing cheese whey and used cooking oil and were maintained for 14 and 17 hours in the bioreactor receiving cheese whey and used cooking oil, respectively. Temperatures higher than $60{ }^{\circ} \mathrm{C}$ were also observed in the bioreactors receiving cheese whey and used cooking oil and were maintained for 9 hours.

Heat was generated as a result of the degradation of organic matter which raised the temperature inside the bioreactor first to the mesophilic stage $\left(25-45{ }^{\circ} \mathrm{C}\right)$ and then to the thermophilic stage $\left(40-63^{\circ} \mathrm{C}\right)$. The lag period of the mesophilic (first lag) and thermophilic (second lag) phases as well as the rates of temperature increase during the two phases were determined graphically according to the procedure described by Ghaly et al (1989) as shown in Fig. 5. The results are also illustrated in Table 6. Figure 6 shows the various kinetic parameters of these experiments. The mesophilic lag period was 3,15 and $12 \mathrm{~h}$ and the rate of mesophilic temperature increase was $2.17,1.63$ and $2.28{ }^{\circ} \mathrm{C} \mathrm{h}^{-1}$ for the control and the mixtures receiving cheese whey and used cooking oil, respectively. The thermophilic lag period was 50,17 and $0 \mathrm{~h}$ and the rate of thermophilic temperature increase was $0.85,2.24$ and $2.28{ }^{\circ} \mathrm{C} \mathrm{h}^{-1}$ for the control and the mixtures receiving cheese whey and used cooking oil, respectively.

Composting microorganisms adjusted much faster to oil as a nutrient compared to cheese whey. This could be due to the availability of only one source of carbon (fat) in used cooking oil compared to fat and lactose in the cheese whey ${ }^{[18-20]}$. Although, both mixtures had the same energy content, the carbon in the used cooking oil seems to be more accessible to microbes than that in the cheese whey lactose. Shuler and Kargi ${ }^{[19]}$ stated that different microorganisms have different favorable carbon sources and when the favorable carbon sources is available, microbes will not expend energy to create a pathway for utilization of a less favorable one unless the favorable sources is low or depleted. The phenomenon of diauxic growth, which refers to the sequential use of different carbon sources or sequential population growth, was observed in this study. Monod ${ }^{[18]}$ observed diauxic growth on two carbon sources: glucose and lactose. In his study,

\begin{tabular}{lcccc} 
Table 6: & Composting kinetic parameters & \\
\hline Treatment & Mesophilic Range & Thermophilic Range \\
& Lag Time & Rate & Time & Rate \\
& ------- & ---- & ---- \\
& $(h)$ & $\left({ }^{\circ} \mathrm{C} / \mathrm{h}\right)$ & $(\mathrm{h})$ & $\left({ }^{\circ} \mathrm{C} / \mathrm{h}\right)$ \\
\hline Control & 3 & 2.17 & 5 & 0.85 \\
Cheese Whey & 15 & 1.63 & 17 & 2.24 \\
Used Cooking Oil & 12 & 2.28 & 0 & 2.28 \\
\hline
\end{tabular}

$40{ }^{\circ} \mathrm{C}$ was considered to be the end of mesophilic stage and the beginning of the thermophilic stage.

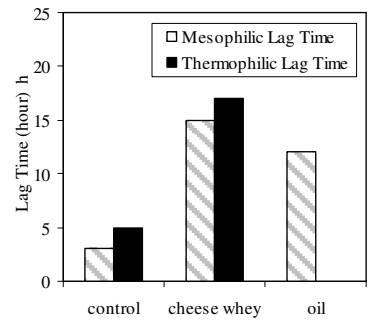

a. Lag time

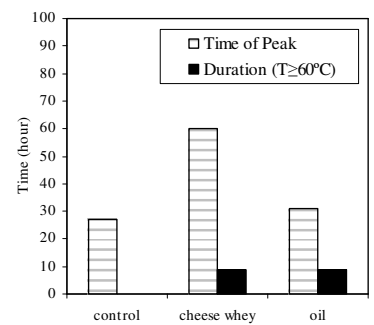

b. Time of peak and duration

d. Maximum temperature reached

Fig. 6: Effect of bioavailable carbon addition on the kinetic parameters of the composting process

microbes grew first exponentially on glucose as the preferred carbon source, a lag period was noticed after glucose was depleted during which the enzymes necessary for growth on lactose was synthesized, then microbes grow again exponentially on lactose until it was depleted. The phenomenon was also reported by Ghaly $e t a l .{ }^{[21]}$ for a mixed culture grown in liquid swine manure and by Alkoik and Ghaly ${ }^{[8]}$ during composting of plant residues.

The $\mathrm{pH}$ value of the mixture receiving cheese whey was about $5.0-5.5$. Sundberg et al. ${ }^{[22]}$ reported very small carbon dioxide production in samples with an initial $\mathrm{pH}$ lower than 6.0. Thus, the longer mesophilic lag period observed with the mixture receiving cheese whey could be the result of low $\mathrm{pH}$. Several researchers ${ }^{[22-24]}$ reported decline in microbial activity during the transition from mesophilic stage to thermophilic stage when composting acidic material ( $\mathrm{pH} \sim 4.5-5.5)$.

The time of peak was affected by the type of carbon added to the mixture. The maximum temperature was achieved after $31 \mathrm{~h}$ of composting the mixture with used cooking oil, while it took double the time $(60 \mathrm{~h})$ for the temperature to peak during the composting process of the mixture with cheese whey due to the long lag periods (the initial lag period caused 
by lower $\mathrm{pH}$ and the thermophilic lag period caused by the shift from fat to lactose as a source of carbon). VanderGheynst et $a l^{[25]}$ reported that a maximum temperature of $60{ }^{\circ} \mathrm{C}$ was obtained after $56 \mathrm{~h}$ and was maintained for $344 \mathrm{~h}$ during the composting process of a synthetic food waste and digested biosolids in a pilotscale $\left(0.77 \mathrm{~m}^{3}\right)$ bioreactor ( 5 and $12.5 \mathrm{~h}$ for mesophilic and thermophilic lag periods, respectively). The maximum temperature and lag period reported by the authors were similar to the calculated values in the current study for the control and the oil experiments. However, the maximum temperature was maintained for a shorter time in this study due to the smaller compost mass utilized ( $3.5 \mathrm{~kg} \mathrm{wb})$.

Thermophilic composting is preferred when dealing with material infected with pathogens ${ }^{[26-29]}$ or contaminated with pesticides ${ }^{[30-35]}$. These authors indicated that the temperature and time relation is considered to be the most reliable parameter for prediction of pathogens inactivation and pesticide destruction. The maximum temperature obtained with the used cooking oil $\left(63.3^{\circ} \mathrm{C}\right)$, combined with the uniform temperature distribution provided by the continuous mixing, suggests that current composting process will be effective in destroying the pathogens and pesticides. However, the duration of high temperature should be extended by continuous addition of used cooking oil as a bioavailable carbon source.

Moisture: The initial moisture contents of all mixtures were adjusted to approximately $60 \% \pm 0.70 \%$. The final moisture content was approximately $59.7 \pm 0.61 \%$ as shown in Table 7 . Even though continuous aeration was supplied, little changes were observed in the moisture content of the material during composting. The final moisture content was within the optimum range of $50-60 \%$ reported by Liang et al. ${ }^{[36]}$ and Richard et $a l .^{[37]}$ and was not, therefore, a limiting factor in this study.

Drying potential of the composting material is considered a serious problem challenging researchers ${ }^{\text {[36- }}$ 39]. Significant moisture content reduction (45\%) was reported by Walker et al. ${ }^{[38]}$ after 13 to 20 days of composting. Although high temperature was reached during this study, the moisture content stayed relatively unchanged. This could be due to the short composting time ( $<5$ days) and the compensation of water lost with the exhaust by the water produced as a by-product of degradation process during the initial active stage of composting according to equation 5 .

Volatile solids: The initial and final volatile solids concentrations were $872.0,872.0$ and $871.9 \mathrm{~g} \mathrm{~kg}^{-1}$ and $710.0,678.4$ and $618.2 \mathrm{~g} \mathrm{~kg}^{-1}$ giving reductions of 18.5 , 22.2 and $29.1 \%$ for the control and the mixtures receiving cheese whey and used cooking oil, respectively (Table 7). The results showed that the addition of cheese whey and used cooking oil has
Table 7: Changes in the biological parameters of the composting process

\begin{tabular}{|c|c|c|c|}
\hline Parameter & Control & $\begin{array}{l}\text { Cheese } \\
\text { Whey }\end{array}$ & $\begin{array}{l}\text { Used } \\
\text { Cooking Oi }\end{array}$ \\
\hline \multicolumn{4}{|l|}{$\overline{\mathrm{MC}}$} \\
\hline Initial & 61.7 & 60.3 & 61.0 \\
\hline Final & 59.9 & 58.9 & 59.0 \\
\hline Reduction (\%) & 2.9 & 2.3 & 3.3 \\
\hline \multicolumn{4}{|l|}{ Volatile Solids $^{+}$} \\
\hline Initial $\quad(g / k g)$ & 872.0 & 872.0 & 871.9 \\
\hline Final $\quad(\mathrm{g} / \mathrm{kg})$ & 710.6 & 678.4 & 618.2 \\
\hline Reduction (\%) & 18.5 & 22.2 & 29.1 \\
\hline \multicolumn{4}{|c|}{ Total Carbohydrates } \\
\hline Initial $\quad(\mathrm{g} / \mathrm{kg})$ & 775.0 & 738.6 & 735.0 \\
\hline Final $\quad(\mathrm{g} / \mathrm{kg})$ & 608.7 & 560.0 & 502.1 \\
\hline Reduction (\%) & 21.5 & 24.2 & 31.7 \\
\hline \multicolumn{4}{|c|}{ Total Fat and Grease ${ }^{+}$} \\
\hline Initial $\quad(\mathrm{g} / \mathrm{kg})$ & 14.7 & 23.7 & 56.3 \\
\hline Final $\quad(g / k g)$ & 5.2 & 5.6 & 6.3 \\
\hline Reduction (\%) & 64.6 & 76.4 & 88.8 \\
\hline \multicolumn{4}{|l|}{$\mathrm{TKN}^{-\mathrm{N}^{+}}$} \\
\hline Initial $\quad(\mathrm{g} / \mathrm{kg})$ & 14.3 & 18.7 & 14.5 \\
\hline Final $\quad(g / k g)$ & 13.8 & 15.4 & 12.9 \\
\hline Reduction (\%) & 3.50 & 17.70 & 11.04 \\
\hline \multicolumn{4}{|l|}{$\mathrm{NH}_{4}-\mathrm{N}^{+}$} \\
\hline Initial $\quad(\mathrm{g} / \mathrm{kg})$ & 3.3 & 3.5 & 3.4 \\
\hline$(\mathrm{g} / \mathrm{kg})$ & 3.3 & 3.4 & 3.5 \\
\hline Reduction (\%) & 0 & 0 & -2.9 \\
\hline \multicolumn{4}{|l|}{ Crude Proteins } \\
\hline Initial $\quad(\mathrm{g} / \mathrm{kg})$ & 82.3 & 109.0 & 80.6 \\
\hline Final $\quad(g / k g)$ & 72.1 & 82.1 & 66.3 \\
\hline Reduction $(\%)$ & 12.4 & 25.3 & 17.8 \\
\hline
\end{tabular}

+ Calculated based on the dry matter basis.

increased the volatile solid reduction over that of the control. The rates of volatile solids reductions were $0.12,0.14$ and $0.19 \mathrm{~kg} \mathrm{VS} \mathrm{day}^{-1}$ for the control and the mixtures receiving cheese whey and used cooking oil, respectively.

Temperatures in the range of $52-60{ }^{\circ} \mathrm{C}$ have been reported to be the optimum for biological degradation during the composting process ${ }^{[40-42]}$. Both cheese whey and used cooking oil experiments reached temperatures $\geq 55^{\circ} \mathrm{C}$. However, a longer higher temperature period (thermophilic stage) was observed with used cooking oil than that observed with the cheese whey and as a result a higher reduction rate of volatile solids was achieved. The biodegradable portion of volatile solids (bioavailable carbon in the form of carbohydrates, proteins and fats) is utilized by microorganisms for energy (equation 5) which results in increased temperature of the compost material ${ }^{[10,36]}$. The duration of temperature $\geq 55^{\circ} \mathrm{C}$ correlated $\left(\mathrm{R}^{2}=0.74\right)$ with the reduction in the volatile solids as shown by the following equation:

$\mathrm{D}=17.98+0.51(\mathrm{VSR})$

Where:

D Duration of temperature $\geq 55^{\circ} \mathrm{C}(\mathrm{h})$.

VSR Reduction in volatile solids (\%).

Total carbohydrate: The initial and final total carbohydrate concentrations were 775.0, 738.6 and $735.0 \mathrm{~g} \mathrm{~kg}^{-1}$ and $608.7,560.0$ and $502.1 \mathrm{~g} \mathrm{~kg}^{-1}$ giving reductions of $21.5,24.2$ and $31.7 \%$ for the control and 
the mixtures with cheese whey and used cooking oil, respectively. Higher reductions in soluble forms of carbohydrates (60-86 \%) were reported by SannchezMonedero et al. ${ }^{[43]}$, Hsu and Lo ${ }^{[44]}$ and Mishra et al. ${ }^{[45]}$ Wood shavings and tomato remains are mostly lignocellulosic materials that have initial high nonbioavailable carbohydrates. Therefore, the reductions in total carbohydrates were relatively smaller in the present study. However, it appears that the used cooking oil experiment achieved higher temperature for a longer period of time which resulted in more nonbioavailable carbon becoming available through biodegradation. Similar findings were reported by Palm and Sanchez ${ }^{[46]}$ who stated that the breakdown of complex carbohydrates is accelerated under higher temperature. A strong correlation $\left(\mathrm{R}^{2}=0.99\right)$ was found between the total carbohydrates reduction and the maximum temperature reached as shown by the following equation:

$\mathrm{T}_{\mathrm{m}}=43.44+0.62(\mathrm{TCR})$

Where:

$\mathrm{T}_{\mathrm{m}}$ Maximum temperature $\left({ }^{\circ} \mathrm{C}\right)$.

TCR Total carbohydrates reduction (\%).

Total fat and grease: The initial and final fat and grease concentrations were 14.7 and 23.7 and $56.3 \mathrm{~g}$ $\mathrm{kg}^{-1}$ and $5.2,5.6$ and $6.3 \mathrm{~g} \mathrm{~kg}^{-1}$ giving reductions of 64.6, 76.4 and $88.8 \%$ for the control and the mixtures with cheese whey and used cooking oil, respectively. The results indicated that the carbon in the oil was readily available to indigenous microorganisms.

The results obtained from the used cooking oil experiment are in agreement with those of Fernandes et $a l .{ }^{[47]}$ and Veil et al. ${ }^{[48]}$ who reported $85-95 \%$ reduction in lipids. Viel et al. ${ }^{[48]}$ reported that most of the thermal energy released was due to the degradation of fats. Higher fats reduction (97\%) was also reported by Baddi et al. ${ }^{[49]}$ after composting a mixture of olive-mill wastes and wheat straw for one year. Sasaki et al. ${ }^{[50]}$ reported a reduction of up to $80 \%$ of used soybean oil and $85 \%$ of expired mayonnaise fat were achieved by the end of the composting experiment. A strong correlation $(\mathrm{R} 2=0.93)$ was found between the total fat and grease reduction and the duration of high temperature $\left(\geq 55^{\circ} \mathrm{C}\right)$ of the compost as shown in equation (9). Similar finding was reported by Fernando et al. ${ }^{[47]}$.

$\mathrm{D}=-25.82+0.49(\mathrm{TFGR})$

Where:

D Duration of temperature $\geq 55^{\circ} \mathrm{C}(\mathrm{h})$.

TFGR Reduction in total fat and grease (\%).

Total Kjeldahl and ammonium nitrogen: The initial and final TKN in the mixture were 14.3, 18.7 and 14.5 $\mathrm{g} \mathrm{kg}^{-1}$ and $13.8,15.4$ and $12.9 \mathrm{~g} \mathrm{~kg}^{-1}$ giving reductions of $3.50,17.70$ and $11.04 \%$ for the control and the mixtures with the cheese whey and used cooking oil, respectively (Table 7). The TKN reduction in cheese whey and used cooking oil experiments were higher than that of the control experiment. de Bertoldi et al. ${ }^{[51]}$, Diaz et al. ${ }^{[52]}$, Hamoda et al. ${ }^{[53]}$ and Martins and Dewes $^{[54]}$ reported that nitrogen loss during in-vessel composting process is influenced by many factors including carbon bioavailability (or $\mathrm{C}$ : $\mathrm{N}$ ratio). The initial and final $\mathrm{NH}_{4}-\mathrm{N}$ concentrations were 3.3, 3.5 and $3.4 \mathrm{~g} \mathrm{~kg}^{-1}$ and $3.4,3.5$ and $3.5 \mathrm{~g} \mathrm{~kg}^{-1}$ for the control and the mixtures with the cheese whey and used cooking oil, respectively. There was no change in the $\mathrm{NH}_{4}-\mathrm{N}$ concentration as the rate of conversion of organic nitrogen was equivalent to the rate of conversion of $\mathrm{NH}_{4}-\mathrm{N}$ to organic nitrogen (microbial cells). However, the degradation of organic nitrogen was faster than the microbial growth in the case of the mixture with used cooking oil due to the higher temperature achieved in this bioreactor.

Crude protein: The initial and final protein concentrations were $82.3,109.0$ and $80.6 \mathrm{~g} \mathrm{~kg}^{-1}$ and $72.1,82.1$ and $66.3 \mathrm{~g} \mathrm{~kg}^{-1}$ giving reductions of 12.4 , 25.3 and $17.8 \%$ for the control and the mixtures with cheese whey and used cooking oil, respectively. A decrease in protein content was also reported by $\mathrm{Hsu}$ and $\mathrm{Lo}^{[44]}$. Proteins undergo enzymatic oxidation to form complex amino compounds, which can then be synthesized into microorganisms or undergo additional decomposition into simpler products ${ }^{[55]}$. The products of the digestion of the proteins and complex amino acids can only be used in the synthesis of new cellular material if sufficient carbon is available ${ }^{[56]}$. Otherwise, unstable nitrogen forms $\left(\mathrm{NH}_{3}\right.$ and $\left.\mathrm{NH}_{4}^{+}\right)$will accumulate and become susceptible to volatilization.

\section{CONCLUSION}

The result of this study indicated that the addition of bioavailable source of carbon (sugar, cheese whey or used cooking oil) to the tomato residues-wood shavings-compost mixture elevated the average bioreactor temperature into the thermophilic zone. The maximum temperatures achieved in all bioreactors (and their durations) were influenced by the type of bioavailable carbons. The maximum temperatures were 50.8, 56.9, 63.4 and $63.3{ }^{\circ} \mathrm{C}$ which lasted 5, 7, 9 and $9 \mathrm{~h}$ for control and mixtures receiving sugar, cheese whey and used cooking oil, respectively. Strong correlations were observed between the maximum temperature achieved and its duration and the reductions in fat and volatile solids. The total carbohydrates reductions were in the range of $21.5-31.7 \%$, the protein reductions were in the range of $12.4-25.3 \%$, the fat reductions were in the range of $64.6-88.8 \%$ and the TKN reductions were in the range of 3.5-17.7 \%. The $\mathrm{NH}_{4}$ remained unchanged $(0.33-0.35 \%)$ and the moisture content remained at $59.7 \pm 0.61 \%$. Neither the nitrogen nor the moisture contents were limiting factors. The maximum 
temperature obtained in this study, combined with the uniform temperature distribution provided by continuous mixing, suggests that the composting process will be effective in destroying the pathogens and pesticides. However, the duration of the high temperature should be extended by continuous addition of a bioavailable carbon source (used cooking oil).

\section{ACKNOWLEDGEMENTS}

This research was funded by the National Science and Research Council of Canada (NSERC). The financial support provided by the Government of Saudi Arabia is highly appreciated.

\section{REFERENCES}

1. AAFC, 2001. Profile of the Canadian greenhouse tomato industry. Agriculture and Agri-Food Canada, Industry Highlights Report. Ottawa, Ontario.

2. ODAF, 2004. Best management practices. Ontario Department of Agriculture and Food. Horticultural Crops. Toronto, Ontario.

3. Conway, K.E., 1996. An overview of the influence of sustainable agricultural systems on plant diseases. Crop Protection, 15: 223-28.

4. NSDAFF, 2004. Environmental Guidelines for Nursery and Turf Industry, Best Agricultural Waste Management Plans. Nova Scotia Department of Agriculture, Food and Fisheries. Halifax, Nova Scotia.

5. Barreveld, W.H., 1989. Rural use of lignocellulosic residues. Food and Agricultural Organization of the United Nations (FAO). Rome, Italy.

6. Brown, A., 1985. Review of lignin in biomass. J. Appl. Biochem., 7: 371-387.

7. Elwell, D.L., H.M. Keener and R.C. Hansen, 1996. Controlled, high rate composting of mixtures of food residues, yard trimmings and chicken manure. Compost Science and Utilization, 4: 6-15.

8. Alkoaik, F. and. A.E. Ghaly, 2005. Effect of inoculum size on the composting of tomato plant trimmings. Compost Science and Utilization, 13: 262-273.

9. Manios, V. and C. Balis, 1983. Respirometry to determine optimum conditions for the biodegradation of extracted olive press-cake. Soil Biol. Biochem., 15: 75-83.
10. Haug, R.T., 1993. The Practical Handbook of Composting Engineering. Lewis Publisher. Boca Raton, Florida.

11. Kunii, D. and O. Levenspiel, 1991. Fluidization Engineering, $2^{\text {nd }}$ ed. Butterworth-Heinemann. Newton, MA.

12. ASTM, 2001. Annual of ASTM Standard Methods. American Society for Testing and Materials, Philadelphia, Pennsylvania.

13. EPA, 1999. Method 1664, Revision An-Hexane Extractable Material (HEM; Oil and Grease) and Silica Gel Treated n-Hexane Extractable Material (SGT-HEM; Non-polar Material) by Extraction and Gravimetric. EPA-821-R-98-002. United States Environmental Protection Agency, office of water. Washington, DC.

14. Juma, N.G. and W.B. McGill, 1986. Decomposition and Nutrient Cycling in Agroecosystems. In Microflora and Faunal Interactions in Natural and Agro-ecosystems, M. J. Mitchell and J. P. Nakas (Eds.). Junk Publishers, Boston, Mass., pp: 74-137.

15. Chen, Y. and Y. Inbar, 1993. Chemical and Spectroscopical Analyses of Organic Matter Transformations During Composting in Relation to Compost Maturity. In: Science and Engineering of Composting: Design, Environmental, Microbiological and Utilization Aspects. H. A. J. Hoitink and H. M. Keener (Eds). Renaissance Publications, Worthington, OH., pp. 551-600.

16. Pagan, J.D., 1997. Measuring the digestible energy content of horse feeds. Equine Nutrition Conference, Kentucky Equine Research Inc., Versailles, Kentucky.

17. Rahn, C.R. and R.D. Lillywhite, 2001. A study of the quality factors affection the short-term decomposition of field vegetable residues. J. Sci. Food and Agri., 82: 19-26.

18. Monod, J., 1947. The phenomenon of enzymatic adaptation. Growth Symp., 11: 223-289.

19. Shuler, M.L. and F. Kargi, 1992. Bioprocess Engineering. Prentice-Hall, Inc. Englewood Cliffs, New Jersey.

20. Talaro, K.P. and A. Talaro, 1999. Foundations in Microbiology. 3rd Edn. McGraw-Hill Companies, Inc. NY, New York.

21. Ghaly, A.E., R. Kok and J. M Ingrahm, 1989. Growth rate determination of heterogeneous microbial population in swine manure. Appl. Biochem. Biotechnol., 22: 59-78. 
22. Sundberg, C., S. Smårs and H. Jönsson, 2004. Low $\mathrm{pH}$ as an inhibiting factor in the transition from mesophilic to thermophilic phase in composting. Biores. Technol., 95: 145-150.

23. Beck-Friis, B., S. Smårs, H. Jönsson and H. Kirchmann, 2001. Gaseous emissions of carbon dioxide, ammonia, nitrous oxide from organic household waste in a compost reactor under different temperature regimes. J. Agril. Engg. Res., 78: 423-430.

24. Weppen, P., 2001. Process calorimetry on composting of municipal organic wastes. Biomass and Bioenergy, 21: 289-299.

25. VanderGheynst, J.S., L.P. Walker and J.Y. Parlange, 1997. Energy Transport in a High-Solids Aerobic Degradation Process: mathematical modeling and analysis. Biotechnol. Progress, 13: 238-248.

26. Hogland, W., T. Bramryd, M. Marques and S. Nimmermark., 2003. Physical, chemical and biological processes for optimizing decentralized small-scale household composting. Compost Science and Utilization, 11: 330-336.

27. Ryckeboer, J., S. Cops and J. Coosemans, 2002. The fate of plant pathogens and seeds during anaerobic digestion and aerobic composting of source separated household wastes. Compost Science and Utilization, 10: 204-216.

28. Haug, R.T., 1980. Compost Engineering: Principles and Practice. Ann Arbor Science Publishers. St. Joseph, MI.

29. Bruns, C., A. Gottschall, W. Zeller, B. Schueler and H. Vogtmann, 1993. Survival Rates of Plant Pathogens During Composting of Biogenic Wastes in Commercial Composting Plants under Different Decomposition Conditions. In: Paoletti M. G., Fossner W., Coleman D. (Eds). Soil Biota, Nutrients Cycling and Farming System. Lewis Publishers. Boca Raton, FL.

30. Fogg, P., A.B. Boxall, A. Walker and A. Jukes., 2003. Pesticide degradation in a biobed composting substrate. Pest Manage. Sci., 59: 527537.

31. Valzano, F., 2000. A Literature review on the composting of composite wood products. The University of New South Wales, Sydney, Australia

32. Wu, J. and D.L. Nofziger, 1999. Incorporating temperature effects on pesticide degradation into a management model. J. Environ. Qual., 28: 92-100.

33. Fogarty, A.M. and O.H. Tuovinen, 1991. Microbiological degradation of pesticides in yard waste composting. Microbiol. Rev., 55: 225-233.

34. Racke, K.D. and C.R. Frink, 1989. Fate of organic contaminants during sewage sludge composting. Bull. Environ. Contamin. Toxicol., 42: 533.
35. Bollag, J.-M. and S.-Y. Liu., 1990. Biological Transformation Processes of Pesticides. In: Pesticides in the Soil Environment: Processes, Impacts and Modeling. H.H. Cheng (Ed.), SSSA Book Series No. 2, Madison, WI.

36. Liang, C., K.C. Das and R.W. McClendon, 2003. The influence of temperature and moisture contents regimes on the aerobic microbial activity of a biosolids composting blend. Biores. Technol., 86: 131-137.

37. Richard, T.L., H.V.M. Hamelers, A. Veeken and T. Silva, 2002. Moisture relationships in composting processes. Compost Science and Utilization, 10: 286-302.

38. Walker, L.P., T.D. Nock, J.M. Gossett and J.S. VanderGheynst, 1999. The role of periodic agitation and water addition in managing moisture limitations during high-solids aerobic decomposition. Process Biochem., 34: 601-612.

39. Diaz, L.F., G.M. Savage, L.L. Eggerth and C.G. Golueke, 1993. Composting and Recycling of Municipal Solid Waste. Lewis Publishers. Boca Raton, Florida.

40. MacGregor, S.T., F.C. Miller, K.M. Psarianos and M.S. Finstein, 1981. Composting process control based on interaction between microbial heat output and temperature. Appl. Environ. Microbiol., 41: 1321-1330.

41. Bach, P.D., M. Shoda and H. Kubota, 1984. Rate of composting of dewatered sewage sludge in continuously mixed isothermal reactor. J. Fermen. Technol., 62: 285-291.

42. Joshua, R., J.M. Barry and J.M. Howard, 1998. Characterization of temperature and oxygen profiles in windrow processing systems. Compost Science and Utilization, 6: 15-28.

43. Sanchez-Monedero, M.A., A. Roig, C. Paredes and M.P. Bernal, 1999. Relationships between watersoluble carbohydrate and phenol fractions and the humification indices of different organic wastes during composting. Biores. Technol., 70: 193-201.

44. Hsu, J.-H. and S.-L. Lo, 1999. Chemical and spectroscopic analysis of organic matter transformations during composting of pig manure. Environ. Poll., 104: 189-196.

45. Mishra, B.K., A. Arora and Lata, 2004. Optimization of a biological process for treating potato chips industry wastewater using a mixed culture of Aspergillus foetidus and Aspergillus niger. Biores. Technol., 94: 9-12. 
46. Palm, C.A. and P.A. Sanchez, 1991. Nitrogen release from the leaves of some tropical legumes as affected by their lignin and polyphenolic contents. Soil Biol. Biochem., 223: 83-88.

47. Fernandes, F., M. Viel, D. Sayag and L. André, 1988. Microbial breakdown of fats through invessel co-composting of agricultural and urban wastes. Biological Wastes, 26: 33-48.

48. Viel, M., D. Sayag and L. André, 1987. Optimization of Agricultural Industrial Wastes Management Through In-vessel Composting. In Compost: Production, Quality and Use. M. de Bertoldi, M.P. Ferranti, P.L. Hermite and F. Zucconi (Eds.), Elsevier Applied Science. London, UK, pp: 230-237.

49. Baddi, G.A., J.A. Alburquerqueb, J. Gonzalvez, J. Cegarra and M. Hafidi, 2004. Chemical and spectroscopic analyses of organic matter transformations during composting of olive mill wastes. Intl. Biodeterioration and Biodegradation, 54: $39-44$.

50. Sasaki, N., K. Suehara and J. Kohda, 2003. Effects of $\mathrm{C} / \mathrm{N}$ ratio and $\mathrm{pH}$ of raw materials on oil degradation efficiency in a compost fermentation process. J. Biosci. Bioengg., 96: 47-52.
51. de Bertoldi M., G. Vallini, A. Pera and F. Zucconi, 1982. Comparison of three windrows compost system. Biocycle, 23: 45-50.

52. Diaz, M.J, E. Madejón, F. López, R. López and F. Cabrera, 2002. Optimization of the rate vinasse/grape marc for co-composting process. Process Biochem., 37: 1143-1150.

53. Hamoda, M.F., H.A. Abu Qdais and J. Newham, 1998. Evaluation of municipal solid waste composting kinetics, resources. Conservation and Recycling, 23: 209-223.

54. Martin, O. and T. Dewes, 1992. Loss of nitrogenous compounds during composting of animal wastes. Biores. Technol., 42: 103-111.

55. Hansen, R.C., M.H. Keener, W.A. Dick, C. Marugg and H.A. Hoitink, 1990. Poultry manure composting ammonia capture and aeration control. Paper No. 90-4062. American Society of Agricultural Engineers, St. Joseph, MI.

56. NEH., 2000. National engineering handbook. United States Department of Agriculture. National Recourses Conservation Service. Washington DC. 